\title{
Leptin Enhances Lung Maturity in the Fetal Rat
}

\author{
SUSAN M. KIRWIN, VINEET BHANDARI, DARLISE DIMATTEO, CAROL BARONE, LINDA JOHNSON, SAPTARASHI PAUL, \\ ALAN R. SPITZER, AVINASH CHANDER, SANDRA G. HASSINK, AND VICKY L. FUNANAGE \\ Departments of Biomedical Research and Pediatrics [S.M.K., D.D., C.B., S.G.H., V.L.F.], Alfred I. duPont Hospital for Children/Nemours \\ Children's Clinic, Wilmington, Delaware, 19803; Department of Pediatrics [V.B., S.P., A.R.S., A.C., S.G.H., V.L.F.], Thomas Jefferson \\ University, Philadelphia, Pennsylvania, 19107; Department of Pediatrics [V.B., L.J], Albert Einstein Medical Center, Philadelphia, \\ Pennsylvania, 19141
}

\begin{abstract}
Pulmonary alveolar type II cells synthesize and secrete phospholipids and surfactant proteins. In most mammalian species, the synthesis of phospholipids and proteins of lung surfactant increases with fetal lung maturation, which occurs late in gestation. Factors that may promote lung maturation and surfactant production include the placental hormone, leptin, whose expression increases with advancing gestational age. We demonstrate that physiologic concentrations of leptin ( 1 and $10 \mathrm{ng} / \mathrm{mL}$ ) increase the levels of surfactant proteins (SP) A, B, and C mRNA as well as SP-A and SP-B protein in d-17 fetal rat lung explants in vitro. To determine whether leptin exerts similar effects in vivo, we administered leptin antenatally to pregnant rats and compared its effects to that of dexamethasone, a known mediator of fetal lung development. Antenatal treatment with leptin for $2 \mathrm{~d}$ significantly increased the average weight of the fetal lungs in relation to their body weight. Histologic analysis revealed that the increase in fetal lung weight was accompanied by an increase in the number and maturation of type II alveolar cells and the expression of surfactant proteins $B$ and $C$ in these cells. Collectively, these results suggest that leptin is a cytokine regulator of rat fetal lung maturity. (Pediatr Res 60: 200-204, 2006)
\end{abstract}

$\mathrm{P}_{\mathrm{a}}^{\mathrm{u}}$ ulmonary surfactant, which lines the alveolar surface, is an absolute requirement for normal lung function as it maintains lung stability and prevents alveolar collapse by reducing surface tension at the air-liquid interface during endexpiration. Pulmonary surfactant is a complex material consisting of phospholipids, neutral lipids, carbohydrate, and proteins. DPPC is the major surface-active component of lung surfactant (1), and phosphatidylglycerol, another major and unique phospholipid, facilitates its surface tension-lowering properties. There are three SP, SP-A, SP-B, and SP-C, which also facilitate the surfactant function of DPPC. Of these, SP-B, which mediates rapid adsorption of DPPC to the airliquid interface, is required to maintain the surface tension-

Received August 2, 2005; accepted March 14, 2006.

Correspondence: Vicky L. Funanage, Ph.D., Department of Biomedical Research, Alfred I. duPont Hospital for Children, 1600 Rockland Rd., Wilmington, DE 19803; e-mail: vfunanag@nemours.org

V.B. is currently at Yale University School of Medicine, Division of Perinatal Medicine, Children's Hospital, New Haven, CT; S.P. is at USV Limited in Govandi, Mumbai; A.C. is at the Department of Pediatrics, State University of New York, Stony Brook, NY; and A.S. is at Pediatrix Medical Group, Sunrise, CA.

S.M.K. and V.B. contributed equally to this study.

Supported by a grant from Nemours Research Programs to V.F. and S.H. and National Heart, Lung and Blood Institute grant number HL49959 to A.C.

DOI: $10.1203 / 01 . p d r .0000227478 .29271 .52$ lowering activity of lung surfactant. Both SP-C and SP-A, in combination with SP-B, further enhance the lowering of surface tension by surfactant phospholipids $(2,3)$. In addition, SP-A is postulated to aid in host-defense mechanisms by affecting macrophage function (4). Alveolar epithelial type II cells synthesize all of these proteins and process the primary translation products to form mature proteins (5).

In most mammalian species, the synthesis of lipids and proteins of lung surfactant increases with fetal lung maturation, which occurs late in gestation (6). The synthesis of SP-A, SP-B, and SP-C mRNA in embryonic rat lung of 13-d gestation can be detected by reverse transcriptase (RT) PCR (7), indicating that cells destined to become type II cells are present early in embryonic life. The typical type II cell morphology with increased number of lamellar bodies is seen at $19 \mathrm{~d}$ of fetal life (term being $22 \mathrm{~d}$ ). At this time, DPPC and SP-A and SP-B proteins also begin to increase (8). Thus, increased production of surfactant does not occur until after $80 \%$ of gestation is completed. As the fetus nears birth, the mature surfactant system is in place to facilitate extrauterine life.

The development of the cultured fetal lung explant model (9-11) has facilitated investigations into regulation of surfactant production. This model preserves tissue architecture and appropriate cell-cell interactions, which seem to be important for differentiation and maintenance of the type II cell phenotype (12). Fetal lung explants in culture undergo spontaneous maturation and demonstrate increased synthesis of DPPC and SP-A $(10,13)$.

Recent studies on the hormone leptin have outlined its role in energy homeostasis, regulating such diverse processes as satiety, fetal and neonatal growth, and immune function (14). Leptin regulates appetite and metabolic activity in mice (15) by acting through the long form of the leptin receptor $(\mathrm{Ob}-\mathrm{Rb})$ in the hypothalamus (14). Leptin-deficient $o b / o b$ mice have a specific respiratory phenotype of alveolar hyperventilation and chronic hypercapnia (16). These phenotypic abnormalities are observed in age- and weight-matched leptin-deficient $(o b / o b)$ mice before pronounced obesity. In a subsequent study, Tankersley et al. (17) demonstrated that leptin administration to ob/ob mice ameliorated the volume-dependent decrease in lung com-

Abbreviations: CC10, Clara cell 10-kD protein; DPPC, dipalmitoyl phosphatidylcholine; SP, surfactant protein 
pliance in these animals. Leptin has also recently been shown to prevent depressed respiration in $o b / o b$ mice (18).

The observation that leptin is synthesized and secreted by human (19), rat (20), and mouse (21) placental tissue may have important implications, inasmuch as it suggests a novel role for leptin in fetal growth and development. Because leptin expression was observed in human placenta from near-term pregnancies and in mouse placenta from $14.5 \mathrm{~d}$ but not from $12 \mathrm{~d}$ of gestation $(21,22)$, it is likely that leptin regulates some aspect of developmental growth in the fetus during the second half of gestation. We propose that leptin is important for lung growth and/or maturation and that the lack of leptin exposure late in pregnancy when the type II alveolar cells are maturing and producing surfactant could contribute to the respiratory distress suffered by many premature infants.

\section{METHODS}

Animals. This study was approved by the Animal Care and Use Committee of Thomas Jefferson University. Timed-pregnant Sprague-Dawley rats were obtained from Charles River Laboratories (Wilmington, MA). Rats were anesthetized with intraperitoneal administration of pentobarbital sodium $(50 \mathrm{mg} / \mathrm{kg})$ and the uterine horns surgically removed. The mothers were then killed by exsanguination. The fetuses were immediately removed from the uterus and placed on ice to induce anesthesia. The lungs en bloc with heart and trachea were removed and placed in Waymouth medium for further processing.

Fetal lung explant. Fetal rat lungs of 17-21 d gestation from two to three pregnant rats were dissected free of heart, trachea, and bronchi, placed in ice-cold serum-free Waymouth medium and cut into $1 \mathrm{~mm}^{3}$ pieces on a McIlwain tissue chopper as described by Gross and Wilson (11). The explants from 33 to 46 pooled fetal lungs were cultured as described (11) for varying periods of time for up to $3 \mathrm{~d}$ to establish a time course for leptin effects on the fetal lung. Mouse recombinant leptin (R\&D Systems, Minneapolis, MN) was added at either 1,10 , or $100 \mathrm{ng} / \mathrm{mL}$ at the time of initiation of the culture (d 0$)$.

Isolation and attachment of type II cells. Type II cells were obtained from the lungs of 19-d gestation fetal rats (term is $22 \mathrm{~d}$ ) by our previously published method $(23,24)$. In brief, lungs were removed, dissected free of connective tissue and nonparenchymal pulmonary tissue, and cultured as explants for 40-48 $\mathrm{h}$ in serum-free Waymouth MB 752/1 medium with penicillin and streptomycin in humidified $95 \% \mathrm{O}_{2} / 5 \% \mathrm{CO}_{2}$ at $37^{\circ} \mathrm{C}$. The explant cells were then harvested and the cells dissociated using a solution of collagenase, trypsin, and DNase. The nonadherent suspension containing an enriched population of fetal type II cells was plated at $2 \times 10^{6}$ cells $/ 35 \mathrm{~mm}^{2}$ dish in $2 \mathrm{~mL}$ of minimum essential medium containing penicillin $(100 \mathrm{U} / \mathrm{mL})$, kanamycin $(100 \mu \mathrm{g} / \mathrm{mL})$, and $2 \%$ fetal bovine serum. The cells were cultured for $20-22 \mathrm{~h}$ at $37^{\circ} \mathrm{C}$ in $5 \% \mathrm{CO}_{2} /$ room air (23).

RT/PCR analysis. Total RNA was extracted by homogenizing the tissue in 4M guanidine thiocyanate, applying the lysate on a QIAGEN RNeasy column (QIAGEN, Chatsworth, CA), and recovering total RNA according to the manufacturer's instructions. Total RNA $(1 \mu \mathrm{g})$ was brought up to $10 \mu \mathrm{L}$ in DEPC-treated water. The sample was heated to $75^{\circ} \mathrm{C}$ for $3 \mathrm{~min}$, placed on ice, and cDNA synthesis was performed by reverse transcription for $15 \mathrm{~min}$ at $42^{\circ} \mathrm{C}$ in a $20 \mu \mathrm{L}$ reaction containing $1 \times$ PCR buffer II (Applied Biosystems, Branchburg, NJ), $5 \mathrm{mM} \mathrm{MgCl}, 1.25 \mathrm{mM}$ each dNTP, $1 \mathrm{U} / \mu \mathrm{L}$ RNasin (Promega, Madison, WI), $12.5 \mu \mathrm{g} / \mu \mathrm{L}$ oligo (dT) ${ }_{15}$, and $2.5 \mathrm{U} / \mu \mathrm{L}$ AMV reverse transcriptase (Promega). Subsequent amplification of the cDNA sequence was performed with $5 \mu \mathrm{L}$ of the reverse transcription reaction in $1 \times$ Taq buffer, 5\% DMSO, 25 pmol each primer (Table 1), and $1.25 \mathrm{U} \mathrm{Taq}$ polymerase in a $25 \mu \mathrm{L}$ reaction volume. For assessment of the relative levels of SP-A, SP-B, and SP-C transcripts, a multiplex RT-PCR reaction with $18 \mathrm{~S}$ rRNA (Ambion, Austin, TX) was used. Since the leptin receptor isoforms all differ in their carboxy terminus, a universal forward primer was used with isoform-specific reverse primers to analyze receptor gene expression (Table 1). The temperature profile for the PCR reactions consisted of a $2 \mathrm{~min}$ melting step at $95^{\circ} \mathrm{C}$, then $24-35$ cycles of $30 \mathrm{~s}$ at $94^{\circ} \mathrm{C}, 30 \mathrm{~s}$ at $55^{\circ} \mathrm{C}$, and $60 \mathrm{~s}$ at $65^{\circ} \mathrm{C}$, followed by a final extension step of $5 \mathrm{~min}$ at $72^{\circ} \mathrm{C}$. RT-PCR products were separated by size on a $4 \%$ agarose gel and stained with ethidium bromide. Images were captured via an Eagle Eye II still video imaging system, and the relative band intensities analyzed with accompanying software (Stratagene, La Jolla, CA).
Table 1. PCR primers and their target genes

\begin{tabular}{lll}
\hline \multicolumn{1}{c}{ Primer } & \multicolumn{1}{c}{ Gene } & \multicolumn{1}{c}{ Sequence } \\
\hline RSPAF & Rat SP-A & 5'CCTCTTCTTGACTGTTGTCGCTGG3' \\
RSPAR & Rat SP-A & 5'GCTGAGGACTCCCATTGTTTGCAG3' \\
RSPBF & Rat SP-B & 5'GGAGCTAATGACCTGTGCCAAGAG3' \\
RSPBR & Rat SP-B & 5'CTGGCCCTGGAAGTAGTCGATAAC3' \\
RSPBR2 & Rat SP-B & 5'AAGTACTGTGTAACGCTCAGCCAG3' \\
RSPCF & Rat SP-C & 5'GATGGAGAGCCCACCGGATTACTC3' \\
RSPCR & Rat SP-C & 5'GAACGATGCCAGTGGAGCCAATAG3' \\
ROBRaF & Rat OB-Ra & 5'AGTGAATGCTGTGCAGTCACTCAG3' \\
ROBRbF & Rat OB-Rb & 5'GGATGAGTGTCAGAGTCAACCCTC3' \\
ROBRaR & Rat OB-Ra & 5'CAAAGAGTGTCCGCTCTCTTTTGG3' \\
ROBRbR & Rat OB-Rb & 5'CAGTTCCAAAAGCTCATCCAACCC3' \\
RCC10F & Rat CC10 & 5'CCATCACAATCACTGTGGTCATGC3' \\
RCC10R & Rat CC10 & 5'CCGTGAGCTTCATGATGTTTATCC3' \\
ACTF1 & Rat $\beta$-actin & 5'TGTATGCCTCTGGTCGTACCAC3' \\
ACTR1 & Rat $\beta$-actin & 5'ACAGAGTACTTGCGCTCAGGAG3' \\
\hline
\end{tabular}

Real-time RT-PCR. RNA concentrations were measured spectrophotometrically (Nanodrop Technologies, Wilmington, DE) and diluted to $50 \mathrm{ng} / \mu \mathrm{L}$ in a total volume of $25 \mu \mathrm{L}$ and treated with DNAse I according to the manufacturer's instructions (Ambion). After DNAse I inactivation, the RNA was purified as described above. RNA (50 ng) was reverse-transcribed using the Sensiscript kit from QIAGEN, and the cDNA (400 ng) was amplified in triplicate with $300 \mathrm{nM}$ of each forward and reverse primer and $1 \times$ SYBR green mix (Bio-Rad, Hercules, CA) in the iCycler (Bio-Rad) with an annealing temperature of $55^{\circ} \mathrm{C}$. The relative amount of mRNA for each sample was calculated using the $2^{-\Delta \Delta \mathrm{Ct}}$ method as described by Livak et al. (25). In short, the triplicate $\mathrm{C}_{\mathrm{t}}$ readings for each gene were averaged and the standard deviations calculated. SP-B and SP-C $\mathrm{C}_{\mathrm{t}} \mathrm{s}$ were normalized to those for $18 \mathrm{~s}$ to obtain $\Delta \mathrm{C}_{\mathrm{t}} \mathrm{s}$ that were used to determine the mRNA relative to $\mathrm{d} 0$ controls.

Antenatal treatment of pregnant rats with leptin or dexamethasone. Leptin (1 mg/kg body weight) was administered to pregnant rats at $\mathrm{d} 16$ of gestation and $24 \mathrm{~h}$ later by intraperitoneal injection. Dexamethasone at $6 \mathrm{mg} / \mathrm{kg}$ body weight was administered at similar time intervals as leptin. After $48 \mathrm{~h}$ of leptin or dexamethasone exposure, the rat pups were surgically removed at $\mathrm{d} 18$, which is similar to $30 \mathrm{wk}$ of gestation in the human. The fetuses from each litter were pooled and weighed, and various tissues from both the rat fetuses and mothers were also dissected and weighed.

Histochemistry and immunohistochemistry. Lung tissue samples were mounted in 8\% Tragacanth gum, snap-frozen in isopentane chilled in liquid nitrogen, and stored at $-70^{\circ} \mathrm{C}$. After equilibrating the sample to $-20^{\circ} \mathrm{C}$, the lungs were sectioned at $5 \mu \mathrm{m}$ on a Jung Frigocut 2800E cryostat (Leica Microsystems, Inc., Deerfield, IL) and lifted onto Probe Plus Slides (Fisher Scientific, Pittsburgh, PA). The slides were briefly postfixed in $2 \%$ paraformaldehyde. Cultured fetal lung explants and type II pneumocytes were directly fixed in $2 \%$ paraformaldehyde.

Fixed tissues and explants were rinsed in PBS (0.1 M, pH 7.4) and blocked for endogenous avidin, biotin, and peroxidase activity. The slides were incubated for $2 \mathrm{~h}$ in a 1:1000 dilution of goat anti-rat polyclonal $\mathrm{IgG}$ antiserum to either SP-B or SP-C (Chemicon International, Temecula, CA). Control sections were incubated in $2 \%$ BSA in PBS. Slides were rinsed in three changes of PBS, 10 min each, and placed in the appropriate biotinylated secondary antibody diluted 1:500, for $30 \mathrm{~min}$. Following the secondary antibody, slides were again rinsed in three changes of PBS, 10 min each, then detected in streptavidin horse radish peroxidase and DAB chromogen (Zymed Laboratories, South San Francisco, CA). The sections were counter stained in Mayer hematoxylin and mounted in Advantage aqueous mounting medium (Innovex Bioscience, Richmond, CA). Stained tissues were viewed with a Dialux 20 microscope and Q500 imaging system (Leica). Photoprints were printed with a Primera color printer (Fargo Electronics, Eden Prairie, MN). The number of SP-B and SP-C- positive cells and total nuclei was determined in random fields from each sample and expressed as a percentage of the total number of nuclei per field, which contained immature airways interfacing with immature mesenchymal tissue.

Type II cells were identified by alkaline phosphatase staining as previously described (26). Unfixed frozen $5 \mu \mathrm{m}$ sections and cell culture slides were stained histochemically with alkaline phosphatase at $\mathrm{pH} 8.74$ to identify type II alveolar cells. Slides were incubated for $60 \mathrm{~min}$ at $37^{\circ} \mathrm{C}$ in $25 \mathrm{~mL}$ of $0.2 \mathrm{M}$ Tris-HCl buffer and $25 \mathrm{~mL}$ of deionized water, $5 \mathrm{mg}$ of naphthol AS-BI phosphate, $0.1 \mathrm{~mL}$ dimethylformamide, and $30 \mathrm{mg}$ of fast red TR. The slides were then rinsed in three changes of deionized water, counterstained for $30 \mathrm{~s}$ 
in Mayer hematoxylin and blued in running water for 3-5 min. Slides were mounted from water in Advantage mounting medium.

Gel electrophoresis and Western blots. Rat lungs were dissected from the fetuses of two to three pregnant rats, the lungs pooled, and then placed into explant culture. Protein was isolated from the explants at the indicated day in culture, and equal amount of total protein was loaded for each sample. Surfactant proteins were separated by electrophoresis on $12 \%$ (for SP-A) and $15 \%$ (for SP-B) polyacrylamide-SDS, and transferred to nitrocellulose membranes by electroblotting. The membranes were blocked with $2 \%$ gelatin (Bio-Rad), treated overnight with appropriate antibody (anti-SP-A or anti-SPB), and then with secondary antibody (goat anti-rabbit HRP-conjugated antibody). The blots were then reacted with a chemiluminescent substrate solution (SuperSignalR, Pierce Chemical Co., Rockville, IL) and exposed to $\mathrm{x}$-ray films to detect proteins that were recognized by the primary antibody. The densities of the reaction products were measured by scanning densitometry and compared with the control group.

Statistical analysis. The Statistical package for the Social Sciences 11.5 (Microsoft, Chicago, IL) was used for all statistical analyses. Statistical differences between control and treated cells were assessed by $t$ test for the means of two samples. Statistical significance was defined as $p<0.05$. Results are presented as mean \pm SEM. One-way ANOVA was used to determine differences in the number of counts for each treatment; significance was determined using Tukey posthoc test.

\section{RESULTS}

Effects of leptin on surfactant production in the fetal lung explant model. We have used a fetal lung explant model to mimic the conditions of the premature lung. Two independent lung explant cultures from 21-d rat fetuses, term being $22 \mathrm{~d}$, were established as described in the "Methods." Leptin at 1, 10 , or $100 \mathrm{ng} / \mathrm{mL}$ (not shown) was added to the explant cultures on the day of establishment of the culture (d 0). The explants were cultured for $3 \mathrm{~d}$, and protein extracts were prepared to establish a time course for leptin effects on the fetal lung. Figure 1 shows that $1 \mathrm{ng} / \mathrm{mL}$ leptin increases SP-B production above that of the control cultures after either 48 or $72 \mathrm{~h}$ of leptin exposure, whereas higher concentrations of leptin increased SP-B production after $24 \mathrm{~h}$, but decreased SP-B levels after 48 and $72 \mathrm{~h}$.

To explore the effect of gestational age on surfactant production in response to leptin, we exposed d-21 fetal lung explants and also younger lung explant cultures (d 15, d 17, d 19) to $1 \mathrm{ng} / \mathrm{mL}$ leptin. We used $18 \mathrm{~S}$ rRNA to determine the relative levels of surfactant mRNA because leptin increased the levels of $\beta$-actin mRNA (data not shown). Since 18S rRNA is much more abundant than any mRNA species,

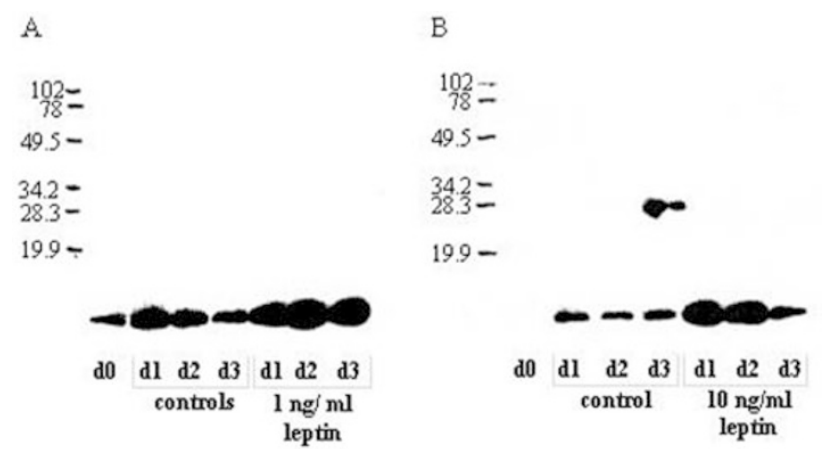

Figure 1. Western blot analysis of SP-B protein from 21-d gestation, fetal rat lung explants cultured in the presence or absence of leptin. Fetal lung explants were exposed to either $(A) 1 \mathrm{ng} / \mathrm{mL}$ or $(B) 10 \mathrm{ng} / \mathrm{mL}$ leptin from initiation of culture (d 0). Explants were harvested and protein extracts were prepared on $\mathrm{d} 1,2$, and 3 of culture. Western blots were probed with an antibody specific to rat SP-B. modified 18S rRNA primers called competimers (Ambion) were used that cannot be extended by Taq polymerase. By adjusting the ratio of competimers to normal 18S rRNA primers, the RT-PCR signal for $18 \mathrm{~S}$ rRNA was decreased to the level of the surfactant mRNAs in control cultures and approximates 1.0, as described in the "Methods." Figure 2 is representative of results obtained from four independent d-17 fetal lung cultures and shows that leptin increased the mRNA levels for SP-A, SP-B, and SP-C relative to the levels of $18 \mathrm{~S}$ rRNA by 1.6-, 5-, and 2-fold, respectively, after $3 \mathrm{~d}$ in culture. However, leptin did not increase surfactant mRNA levels in d-19 or d-21 lung explant cultures after $3 \mathrm{~d}$ in culture (not shown). Real-time PCR also showed that leptin increased SP-B and SP-C mRNA by 18- and 5-fold, respectively in d-17 explants but not in d-19 explants after $3 \mathrm{~d}$ of culture. These results support the hypothesis that leptin has an effect on the maturation of type II alveolar cells as its effect is most pronounced in the immature fetal lung.

To determine whether increased surfactant production in fetal lung explants was due to a direct effect of leptin on the type II alveolar cell, we determined whether the effects of leptin could be reproduced in isolated type II alveolar cells in culture. Alveolar type II cells were obtained from the lungs of 19-d gestation fetal rats, cultured for $24 \mathrm{~h}$, and then exposed to either 1 or $10 \mathrm{ng} / \mathrm{mL}$ leptin for $24 \mathrm{~h}$. Total RNA was isolated from these cells and then examined for SP-A, SP-B, and SP-C mRNA expression as described in the "Methods." A 24-h exposure to $1 \mathrm{ng} / \mathrm{mL}$ leptin slightly increased SP-A, SP-B, and SP-C mRNA levels, whereas $10 \mathrm{ng} / \mathrm{mL}$ leptin only increased SP-A mRNA (data not shown). These results suggest that another cell type in the lung may be mediating or augmenting the effects of leptin on increased surfactant production. A likely candidate is the Clara cell as De Matteis et al. (27) have shown high expression of the long form of the leptin receptor in these cells.

Effect of leptin on leptin receptor and CC10 gene expression in fetal lung explant cultures. Figure 3 shows that fetal lung explant cultures express $\mathrm{CC} 10$ (Clara cell $10-\mathrm{kD}$ protein), an immunohistochemical marker of Clara cells (28), and the level of CC10 mRNA increases as the fetal lung explants mature in culture. Furthermore, both the long $(O B-R b)$ and short $(O B-R a)$ forms of the leptin receptor are expressed in

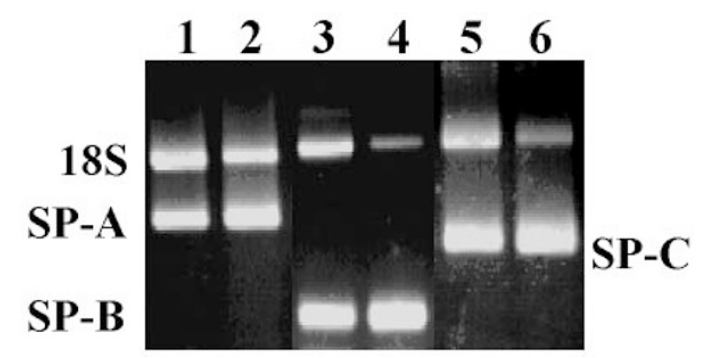

Figure 2. RT-PCR analysis of surfactant mRNA levels relative to $18 \mathrm{~S}$ rRNA in d 17 fetal lung explants. RT-PCR analysis was performed using the Ambion Quantum RNA kit and $1 \mu \mathrm{g}$ of total RNA isolated from explants that had been cultured for 3 d. Lanes 1, 3, 5: fetal lung explants exposed to control medium; lanes 2, 4, 6: fetal lung explants exposed to $1 \mathrm{ng} / \mathrm{mL}$ leptin. The $18 \mathrm{~S}$ rRNA RT-PCR product, present in all lanes, is $488 \mathrm{bp}$. The sizes of the RT-PCR products are 352 bp for SP-A (lanes 1, 2), 201 bp for SP-B (lanes 3, 4), and 284 bp for SP-C (lanes 5, 6). 


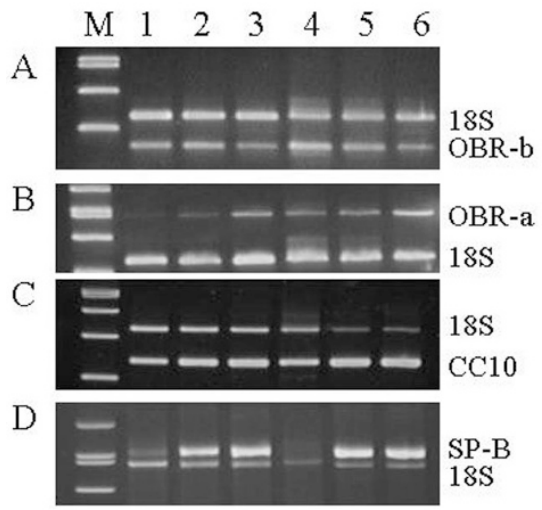

Figure 3. RT-PCR analysis of leptin receptor and $\mathrm{CC} 10$ expression relative to 18S rRNA in d-17 (lanes 1-3) and d-19 (lanes 4-6) fetal lung explant cultures. Total RNA was reverse-transcribed and amplified with $(A) \mathrm{OB}-\mathrm{Rb}$ (262 bp); (B): OB-Ra (480 bp); (C) CC10 (234 bp); (D) SP-B (556 bp). Lanes 1, 4: initiation (d 0 ) of culture; lanes 2, 5: control d 3; lanes 3, 6: $1 \mathrm{ng} / \mathrm{mL}$ leptin, d 3 .

d-17 and d-19 fetal lung explant cultures and leptin decreased expression of $O B-R b$ mRNA and increased expression of $O B-R a$ and CC10 mRNA. CC10 mRNA levels were low in isolated type II cells, in agreement with the fact that these cultures contain 90-95\% type II alveolar cells (not shown).

Antenatal treatment of pregnant rats with leptin. Since glucocorticoids are effective in enhancing lung maturation when administered antenatally, we also tested the effectiveness of antenatal treatment with leptin on fetal lung maturation. Leptin, dexamethasone, or saline was administered to pregnant rats at $\mathrm{d} 16$ of gestation and $24 \mathrm{~h}$ later by intraperitoneal injection as described in the "Methods." Antenatal treatment with leptin significantly increased the average weight of the fetal lungs in relation to their body weight by $14 \%$ (data not shown). Histologic analysis revealed that the increase in fetal lung weight was accompanied by an increase in the number of type II alveolar cells, as evidenced by alkaline phosphatase staining (Fig. 4) and staining for SP-B (Fig. 5) and SP-C protein (Table 2).

\section{DISCUSSION}

Our studies in fetal lung explants and isolated type II alveolar cells support the hypothesis of leptin regulation of the lung surfactant system. Fetal rat lung explants cultured in the presence of leptin demonstrated increased levels of mature

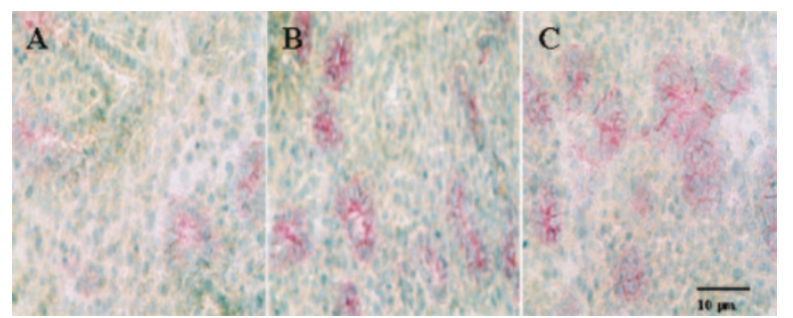

Figure 4. Effect of antenatal treatment with leptin or dexamethasone on fetal lung morphology. Pregnant rats of $16 \mathrm{~d}$ gestation were treated with $(A)$ saline, (B) leptin, or $(C)$ dexamethasone for $48 \mathrm{~h}$ as described in the "Methods." Fetal lung sections were stained with a histochemical stain for alkaline phosphatase, which identifies type II cells.
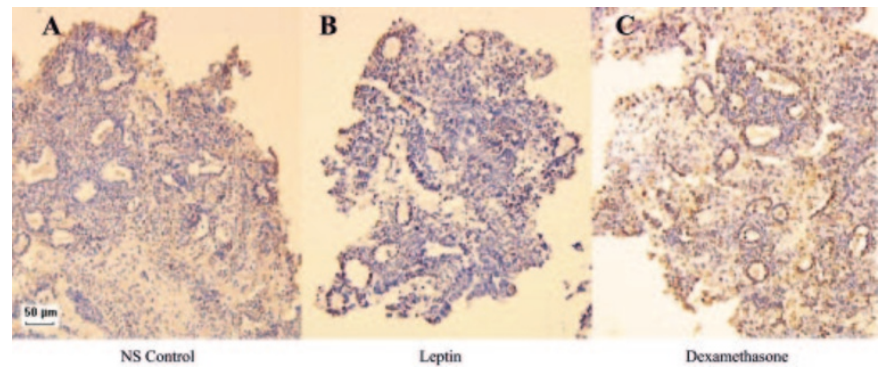

Figure 5. Immunohistochemical analysis of SP-B expression in d 18 fetal lungs antenatally exposed to $(A)$ saline, $(B)$ leptin, or $(C)$ dexamethasone for $48 \mathrm{~h}$. Lung sections were prepared and immunostained for SP-B as described in the "Methods."

SP-A and SP-B protein and of SP-A, SP-B, and SP-C mRNA. Leptin treatment of isolated type II alveolar cultures increased SP-A, SP-B, and SP-C mRNA, but the effect was not as great as that observed in fetal lung explant cultures. Similarly, the long form of the leptin receptor was only detected in fetal lung explant cultures and not in isolated type II alveolar cells. These data suggest that other cell types in the lung are probably necessary for leptin's effect on lung maturation and surfactant production. A potential candidate is the Clara cell, which is the predominant cell type in the lung that expresses the long form of the leptin receptor (27). We show here that CC10 mRNA is expressed in fetal lung explants, that levels increase as the lung explants mature in culture, and that leptin increases the production of CC10 mRNA. CC10 is thought to function as an anti-inflammatory mediator in the lung (29), and $\mathrm{CC} 10$-deficient mice have an altered pulmonary response to hyperoxia (30). The levels of $\mathrm{CC} 10$ increase during fetal lung maturation, and glucocorticoids also enhance CC10 mRNA levels (31). Thus, we speculate that leptin, through binding to $\mathrm{Ob}-\mathrm{Rb}$ on Clara cells and activation of either the JAK2/STAT3 or phosphoinositide 3-kinase signaling pathways, increases expression of $\mathrm{CC} 10 \mathrm{mRNA}$ and secreted protein. The Ob-Ra protein presumably binds and regulates free leptin concentration, but does not have a signaling domain.

Torday et al. (32) have shown that leptin is produced and secreted by the lung lipofibroblast and that dexamethasone and PTH-related protein augment this expression. Further, nonphysiological concentrations of leptin $(100 \mathrm{ng} / \mathrm{mL}$ for $24 \mathrm{~h}$ ) also increased the rate of surfactant phospholipid synthesis and the production of surfactant protein B in d-19 lung explant cultures. Here we demonstrate that physiologic concentrations of leptin (1 and $10 \mathrm{ng} / \mathrm{mL}$ ) increase expression of the surfactant mRNA and proteins in d-17 fetal lung explant cultures. However, leptin did not increase the mRNA levels of SP-A, SP-B, or SP-C in d-19 or -21 fetal lung explants after $3 \mathrm{~d}$ in culture, indicating a temporal regulation of surfactant expression by leptin. This may relate to the observation that the levels of $O b-R b$ mRNA decrease as the lung matures. Chen et al. (33) have shown that $O b-R b$ mRNA was either very low or undetectable in peripheral tissues of adult mice, but expressed at higher levels in the peripheral tissues of newborn mice. Leptin administration decreased expression of $O b-R b$ mRNA and increased expression of $O b-R a$ (short 
Table 2. Percentage of SP-B-and SP-C-positive cells in fetal lungs from pregnant rats treated antenatally with leptin or dexamethasone

\begin{tabular}{lcccc}
\hline Treatment group & $\begin{array}{c}\text { Number of } \\
\text { fields }\end{array}$ & $\begin{array}{c}\text { \%SP-C-positive } \\
\text { cells }\end{array}$ & $\begin{array}{c}\text { Number of } \\
\text { fields }\end{array}$ & $\begin{array}{c}\% \text { SP-B-positive } \\
\text { cells }\end{array}$ \\
\hline Control & 40 & $5.71 \pm 0.67$ & 10 & $3.64 \pm 0.85$ \\
Leptin & 40 & $9.30 \pm 0.93 *$ & 7 & $16.46 \pm 3.87^{*}$ \\
Dexamethasone & 40 & $7.45 \pm 0.78$ & 10 & $6.06 \pm 0.97$ \\
\hline
\end{tabular}

The percentage of SP-C- and SP-B-positive cells relative to total nuclei was determined as described in the "Methods," and mean and SEM are indicated.

$* p=0.005$ compared with control for SP-C and $p<0.001$ compared with control for SP-B, as determined by ANOVA with Tukey post-hoc analysis.

form) mRNA in fetal lung explants (Fig. 3). Collectively, these data support a biologic role for Ob-R during lung development and surfactant gene expression.

Antenatal administration of leptin significantly increased fetal lung weights, due to an increase in type II alveolar cells. Histologic analyses showed that this increase was not due to tissue edema, but to increased cellularity and percentage of cells that express SP-A and SP-B protein. Thus, leptin appears to be a key cytokine regulator of fetal lung maturity.

\section{REFERENCES}

1. Van Golde LG, Batenburg JJ, Robertson B 1988 The pulmonary surfactant system: biochemical aspects and functional significance. Physiol Rev 68:374-455

2. Hawgood S, Shiffer K 1991 Structures and properties of the surfactant-associated proteins. Annu Rev Physiol 53:375-394

3. Whitsett JA 1994 Composition and structure of pulmonary surfactant. In: Boynton BR, Carlo WA, Jobe AH (eds) New Therapies for Neonatal Respiratory Failure. Cambridge University Press, New York, pp 3-15

4. van Iwaarden F, Welmers B, Verhoef J, Haagsman HP, VanGolde LG 1990 Pulmonary surfactant protein A enhances the host-defense mechanisms of rat alveolar macrophages. Am J Respir Cell Mol Biol 2:91-98

5. Weaver TE, Whitsett JA 1991 Function and regulation of expression of pulmonary surfactant-associated proteins. Biochem J 273:249-264

6. Mendelson CR, Boggaram V 1990 Hormonal and developmental regulation of pulmonary surfactant synthesis in fetal lung. Baillieres Clin Endocrinol Metab 4:351-378

7. Wang J, Souza P, Kuliszewski M, Tanswell AK, Post M 1994 Expression of surfactant proteins in embryonic rat lung. Am J Respir Cell Mol Biol 10:222-229

8. Shimizu H, Miyamura K, Kuroki Y 1991 Appearance of surfactant proteins, SP-A, and SP-B, in developing rat lung and the effects of in vivo dexamethasone treatment. Biochim Biophys Acta 1081:53-60

9. Gross I, Ballard PL, Ballard RA, Jones CT, Wilson CM 1983 Corticoid stimulation of phosphatidylcholine synthesis in cultured fetal rabbit lung. Evidence for de novo protein synthesis mediated by glucocorticoid receptors. Endocrinology 112:829-837

10. Gross I, Smith GJ, Maniscalco WM, Czajka MR, Wilson CM, Rooney SA 1978 An organ culture model for study of biochemical development of fetal rat lung. J Appl Physiol 45:355-362

11. Gross I, Wilson CM 1983 Fetal lung maturation: initiation and modulation. J Appl Physiol 55:1725-1732

12. Mendelson CR, Boggaram V 1991 Hormonal control of the surfactant system in fetal lung. Annu Rev Physiol 53:415-440

13. Boggaram V, Mendelson CR 1988 Transcriptional regulation of the gene encoding the major surfactant protein (SP-A) in rabbit fetal lung. J Biol Chem 263:19060-19065

14. Campfield LA, Smith FJ, Burn P 1998 Strategies and potential molecular targets for obesity treatment. Science 280:1383-1387

15. Rohner-Jeanrenaud F, Jeanrenaud B 1996 Obesity, leptin and the brain. N Engl J Med 334:324-325

16. Tankersley C, Kleeberger S, Russ B, Schwartz A, Smith P 1996 Modified control of breathing in genetically obese (ob/ob) mice. J Appl Physiol 81:716-723
17. Tankersley CG, O’Donnell C, Daood MJ, Watchko JF, Mitzner W, Schwartz A, Smith P 1998 Leptin attenuates respiratory complications associated with the obese phenotype. J Appl Physiol 85:2261-2269

18. O’Donnell CP, Schaub CD, Haines AS, Berkowitz DE, Tankersley CG, Schwartz AR, Smith RL 1999 Leptin prevents respiratory depression in obesity. Am J Respir Crit Care Med 159:1477-1484

19. Hassink SG, de Lancey E, Sheslow DV, Smith-Kirwin SM, O'Connor DM, Considine RV, Opentanova I, Dostal K, Spear ML, Leef K, Ash M, Spitzer AR, Funanage VL 1997 Placental leptin: an important new growth factor in intrauterine and neonatal development? Pediatrics 100:E1

20. Chien EK, Hara M, Rouard M, Yano H, Phillippe M, Polonsky KS, Bill GI 1997 Increase in serum leptin and uterine leptin receptor messenger RNA levels during pregnancy in rats. Biochem Biophys Res Commun 237:476-480

21. Hoggard N, Hunter L, Duncan JS, Williams L, Trayhurn P, Mercer JG 1997 Leptin and leptin receptor mRNA and protein expression in the murine fetus and placenta. Proc Natl Acad Sci U S A 94:11073-11078

22. Tomimatsu T, Yamaguchi M, Murakami T, Ogura K, Sakata M, Mitsuda N, Kanzaki T, Kurachi H, Irahara M, Miyake A, Shima K, Aono T, Murata Y 1997 Increase of mouse leptin production by adipose tissue after midpregnancy: gestation profile of serum leptin concentration. Biochem Biophys Res Commun 240:213-215

23. Bhandari V, Lu H, Pachter J, Kresch MJ 1997 Actin polymerization is developmentally regulated in rat type II cells exposed to terbutaline. Pediatr Res 41:166-171

24. Kresch MJ, Dynia DW, Gross I 1987 Culture of differentiated and undifferentiated type II cells from fetal rat lung. Biochim Biophys Acta 930:19-32

25. Livak KJ, Schmittgen TD 2001 Analysis of relative gene expression data using real-time quantitative PCR and the 2(-Delta Delta C(T)) method. Methods 25:402-408

26. Post M, Smith BT 1988 Histochemical and immunocytochemical identification of alveolar type II epithelial cells isolated from fetal rat lung. Am Rev Respir Dis 137:525-530

27. De Matteis R, Dashtipour K, Ognibene A, Cinti S 1998 Localization of leptin receptor splice variants in mouse peripheral tissues by immunohistochemistry. Proc Nutr Soc 57:441-448

28. Singh G, Singh J, Katyal SL, Brown WE, Kramps A, Paradis IL, Dauber JH, Macpherson TA, Squeglia N 1988 Identification, cellular localization, isolation, and characterization of human Clara cell-specific $10 \mathrm{kd}$ protein. J Histochem Cytochem 36:73-80

29. Watson TM, Reynolds SD, Mango GW, Boe IM, Lund J, Stripp BR 2001 Altered lung gene expression in CCSP-null mice suggests immunoregulatory roles for Clara cells. Am J Physiol Lung Cell Mol Physiol 281:L1523-L1530

30. Johnston CJ, Mango GW, Finkelstein JN, Stripp BR 1997 Altered pulmonary response to hyperoxia in Clara cell secretory protein deficient mice. Am J Respir Cell Mol Biol 17:147-155

31. Oshika E, Liu S, Ung LP, Singh G, Shinozuka H, Michalopoulos GK, Katyal SL 1998 Glucocorticoid-induced effects on pattern formation and epithelial cell differentiation in early embryonic rat lungs. Pediatr Res 43:305-314

32. Torday JS, Sun H, Wang L, Torres E, Sunday ME, Rubin LP 2002 Leptin mediates the parathyroid hormone-related protein paracrine stimulation of fetal lung maturation. Am J Physiol Lung Cell Mol Physiol 282:L405-L410; erratum in Am J Physiol Lung Cell Mol Physiol 282: Section L following table of contents, 2002

33. Chen SC, Kochan JP, Campfield LA, Burn P, Smeyne RJ 1999 Splice variants of the OB receptor gene are differentially expressed in brain and peripheral tissues of mice. J Recept Signal Transduct Res 19:245-266 